\title{
Different Forms of Civil Activity and Employment in Hungary and Abroad, and the Development of Student Drop-out
}

\author{
Valéria Markos ${ }^{1}$, Zsófia Kocsis², Ágnes Réka Dusa ${ }^{3}$ \\ Recommended citation: \\ Markos, V., Kocsis, Zs. \& Dusa, A. R. (2019). Different Forms of Civil Activity and Employment in Hungary \\ and Abroad, and the Development of Student Drop-out. Central European Journal of Educational Research, 1(1), \\ 41-54.
}

\begin{abstract}
Young people involved in higher education have created a specific culture, to which, in addition to their studies, social and cultural activities associated with university life are also related (Kozma, 2006). Among these activities, student employment and participation in civic organizations should be highlighted. Voluntary and paid work among higher education students is increasing. These activities have several advantages in terms of future benefits; however, the attracting role of the labour market is one possible reason for dropout. In our current research, we emphasize the role of employment and civil activity in the development of student dropout. Masevičiūtè et al. (2018) found that a quarter of students stopped studying for work-related reasons. In addition, a negative perception of the marketability of the course they are on may lead to the interruption of university studies. In our study, we analysed the extent to which students are willing to interrupt their higher education studies in exchange for voluntary work. In our current research, we examined how often and for what reasons students who dropped out did paid work and volunteering during their studies.
\end{abstract}

Keywords: student emloyment; civil activity; drop out, higher education

\section{Introduction}

In the last few decades, one of the most striking changes in student society has been that young people want to use the services provided by higher education for an extended period of time. As a result, the 'youth' stage of life has been extended, and students have developed an independent culture located at the border of the child and adult cultures (Kozma, 2006). The culture of young people in higher education has created unique institutions and activities, among which student employment and participation in civic organizations should be highlighted (Kozma, 2006). In our study, we examine the relationship between employment, paid and voluntary activity and civic activities, in relation to student dropout. According to the literature, one of the main reasons for dropout can be entry to the labour market and, thereby, paid work during studies, which can be a significant risk factor. Concerning volunteering, research has already revealed how it affects student dropout. Hungarian and international research has already highlighted the positive aspects of volunteering, which has a positive effect on certain performance indicators and competences. In our study, we provide new clarity around the phenomenon of volunteering, and examine the role of volunteering in student dropout, i.e. whether it contributes to preventing it, or encouraging it. Regarding the clusters created on the basis of the reasons given for dropout, we examine the

\footnotetext{
${ }^{1}$ University of Debrecen, Debrecen, Hungary; markosvaleria.90@gmail.com

2 University of Debrecen, Debrecen, Hungary; zsofikocsis6@gmail.com

${ }^{3}$ University of Debrecen, Debrecen, Hungary; dusa.agnes@arts.unideb.hu
} 
characteristics of employment in Hungary and abroad, and the volunteering and civic activities of students.

\section{International overview}

\subsection{Volunteering and civic activity}

The voluntary activity and paid employment of Hungarian higher educational students are both increasing. The results of the Campus Life Survey 2013 showed that $26.1 \%$ of students did voluntary work (Fényes, 2014), while $10 \%$ had paid regular work (11.2\% of female students and $10 \%$ of males). Moreover, $38.8 \%$ of the women and $44.6 \%$ of the men did occasional work (Szőcs, 2013, 2014). The IESA 2015 research shows slightly higher rates, as 38.8\% of students did some kind of voluntary activity and $42.8 \%$ did paid work (Markos, 2018). Regarding volunteering, it can also be observed that the motivation for volunteering is changing. Not only in Hungary but also in Europe, young people are typically motivated by altruistic motivational factors (i.e. motivated by doing activities which are useful for society, acting for others), although individualistic motivational factors (networking, gaining professional experience) have become more important nowadays (Fényes, 2015; Hustinx, 2001). Thus, higher education students are often characterised by a mixture of these two types of motivation (Stefanescu \& Osvat, 2011). Hungary is a country with a low volunteering rate. According to the European Parliamentary Research Service, in 2016 Slovenia, Denmark, Ireland and the Netherlands had the highest proportion of volunteers, while in Poland, Greece and Hungary, only one-sixth of the population did voluntary work (Volunteurope, 2018). The difference between Eastern Central Europe and Western Europe is also visible in terms of volunteering. In Western countries, where democracy is stable, volunteering rates are much higher than in Eastern countries (Juknevičius \& Savicka, 2003).

At the same time, the examination conducted by Bartal (2008) and the data of the Central Bureau for Statistics (2016) show that the proportion of volunteers in Hungary has increased among the population in the 30 years since the end of the communist era. Volunteering has not only changed in numerical terms but also in terms of social statistics. While the ratio of men doing voluntary work was higher following the end of the communist era, that of women increased later on. Regarding age, unpaid work is becoming increasingly popular among elderly people, i.e. in the retired age group. Concerning marital status, married people do voluntary activity more often than they did twenty years ago. While at the end of the communist era, higher education graduates did more volunteering, this kind of activity has become popular among skilled workers and secondary vocational school graduates. A similar trend can be shown in terms of volunteering in different types of settlements across Europe, as it is more typical for the rural population to volunteer than for city dwellers.

An important question during voluntary - but also during paid - work is whether the young person is engaged in activities that are related to his/her studies, as the individual can develop his/her skills and abilities during the activity. In addition, one can also gain knowledge and experience that cannot be found within the college or university. This kind of practical experience can provide a huge advantage for students after they complete their studies and enter the labour market, since volunteering also has a positive effect on employment and income (Baert \& Vujić, 2018). However, it can also motivate the student to interrupt his/her higher educational studies and to choose the world of work (Markos, 2014; Masevičiūte et al., 2018). Research shows that after entering higher education, students often abandon their voluntary activities as they devote more time and energy to their studies (Hustinx et al., 2005). However, in this study, we examine the extent to which students are willing to interrupt their higher educational studies in exchange for the chance to volunteer.

Szabó (2009) emphasises that formal organisations such as schools, political organisations and the church have a huge impact, primarily on civic behaviour. In the typology of Ekman and Amna (2012), the voluntary work of university students and their membership of organisations are a subdimension of latent political activity and civic participation. In our previous work, we examined whether volunteering and embeddedness in civic organisations are protective factors against dropout, or whether they take students' energy away from effective learning (Fényes et al., 2017). 
Our results showed that civic activity neither protects against nor encourages dropout from education. Civic activity can be influenced by numerous factors, and having a good relationship with parents is a key factor in preventing dropout.

According to the results of Pusztai (2017), students with minority status, those with graduate fathers, consumers of 'high' culture, and those having a closer relationship with their lecturers participated more in the work of non-governmental organisations and did voluntary work during their higher educational studies. At the same time, the study also drew attention to the fact that active membership in civic communities increased students' achievement, and increased it even more so than did the various sociodemographic variables (although the relationship capital also had a strong positive impact).

\subsection{The characteristics of student employment in an international context}

Student employment can also be interpreted as a 'double-edged sword', as employment during higher educational studies can have positive effects in the long run, while on the other hand it can reduce the academic achievement of the student and increase the chances of dropout. The main advantage of student employment is that besides earning an income and acquiring work experience, young people can also experience the structure of the labour market which gives them an advantage after graduating (Bocsi et al., 2017; Markos, 2014; Riggert et. al., 2006; Roshchin \& Rudakov, 2015). In addition, working while studying improves students' time management and communication skills, and additionally, working students can also benefit significantly from networking (Beerkens, 2011; Sanchez-Gelabert et al., 2017). For this reason, Pusser (2010) distinguishes between student employment and student work. The former is done for the purpose of earning income while the latter serves to develop the personality, thus increasing the value of student employment.

Before discussing the effects of student employment, it is worth mentioning the characteristic features of student employment while studying at university in an international context. According to the Eurostudent VI data, $51 \%$ of students are employed during their university studies, with $35 \%$ of them doing regular work during the semester and 16\% working periodically. More than half of students have regular work during the semester in the following European countries: Germany (54\%), Estonia (53\%), Latvia, the Czech Republic, and Iceland (49\%). In Hungary, this proportion is $39 \%$ and similar proportions can be seen in the neighbouring countries. Among the countries in the sample, Albania, Italy and Serbia have the lowest rates of student employment, with rates below 15\%. In general, the majority (65\%) of students studying at master level, and $48 \%$ of those studying at bachelor level, are employed (Masevičiūtè et al., 2018).

Student employment is not only increasing in Europe but also overseas. The employment of American students has continued to grow over the past four decades, with more than half of students on average working during the college year (Riggert et al., 2006). It is worth examining the motives for working. In the Eurostudent VI survey, the motivation for work was examined across countries. It can be stated that one of the most frequent motives in the Balkan countries is to pay the tuition-fee, while in countries subsidizing participation in higher education (Denmark, Norway, Sweden, Finland, Malta) students generally do not have to worry about paying tuition fees. Thus, work enables them to increase their standard of living (Masevičiūtė et al., 2018). Increasing university tuition fees and awards among American students have made it increasingly necessary for students to start working after enrolling for university courses (Rowan-Kenyon, 2012). However, in several European countries (Italy, the Czech Republic, France, Georgia), gaining experience outstrips financial motivation as $59 \%$ of students are looking for experience. On average, nearly seven out of ten students said that they work to cover the costs of living. In Finland, Iceland, Latvia and Norway, $80 \%$ of students state that they work because they have to finance their living costs (Masevičiūte et al., 2018).

As in the case of volunteering, the relationship between work and studies is also an important point of analysis. On the basis of Eurostudent VI, more than half of students studying in the Nordic countries have a job related to their studies, while this proportion is lower in the other nations. According to the results, in all countries, master students are more likely to be employed in work 
related to their studies, with the exception of Romania and Slovakia, where hardly any differences can be found between students learning at bachelor or master level (Masevičiūtè et al., 2018). According to Astin (1993), the impact of work on academic achievement is also influenced by whether the student is employed on or off campus, while Pascarella and Terenzini (1998) concluded that modest, inconsistent evidence suggested that any type of work would significantly hinder learning. Working on or off campus did not have a more harmful effect, even if it involved more than 20 hours work per week.

In Hungary, due to the high proportion of students dropping out (36-38\% at bachelor level and $14-17 \%$ at master level), it can be suspected that working intensively while studying at university contributes to a deterioration in academic achievement and delays in meeting academic requirements which will, sooner or later, result in the student dropping out (Derényi, 2015). Consequently, student employment is a risk factor that increases the chances of dropping out of education by drawing students out of the university culture and embedding them in the community, thus reducing the commitment to study and the available study time (Darmody-Smyth, 2008; Perna, 2012; Pusztai, 2011; Riggert et. al, 2006; Stiburek et al., 2017). Previous research has confirmed that the tendency to dropout is higher among students who have long-term, intensive employment (McCoy \& Smyth, 2004; Masevičiūtè et al., 2018). 7\% of Hungarian students discontinued their studies for at least one year, and a quarter of these students referred to work-related reasons as an explanation for this nonactive period. The highest proportions of students interrupting studies (15\% and $14 \%)$ were found in Croatia and Estonia while interrupting studies was least likely (below 5\%) in Germany, Georgia and Slovakia (Masevičiūtė et al., 2018).

The Eurostudent VI survey also showed that working while studying at university has a great impact on student mobility. The potential loss of paid work is the biggest obstacle that prevents employed students - especially those working intensively (i.e. more than 20 hours per week) continuing their studies abroad. In Hungary, $70 \%$ of students do not spend a short period abroad because they would lose their jobs (Masevičiūte et al., 2018). The discontinuation of studies may be caused by a combination of reasons. It is worth mentioning the combination of factors that may enhance the negative impact of employment, such as the familial and financial background of students, the motivation to work or the relationship between the work they do and their studies (Berei, 2018; Bocsi et al., 2018; Dusa et al., 2018). In our research, we focused on the role of employment and civic activity in the dropout process, examining the frequency and reasons for dropout during studies.

\section{The role of volunteering and employment in the development of dropout, based on the DEPART 2018 data}

In our study, we used the database (DEPART 2018) of the Center for Higher Educational Research and Development (CHERD-H), collected in 2018 with support from the National Research, Development and Innovation Office (NKFIH) in the framework of the project entitled 'The role of social and organisational factors in student dropout (Társadalmi és szervezeti tényezők szerepe a hallgatói lemorzsolódásban) OTKA K_123847’. As the first step of our research, we used qualitative methods to explore the reasons for dropout, to understand which factors could increase the risk of dropout. On the basis of the qualitative research phase, a questionnaire survey was conducted, and we searched for former students who had left their higher educational studies without graduating in the last 10 years.

In terms of faculties, we tried to cover a wide range, including natural sciences, engineering, teacher training, arts, medicine, health, military, etc. Thirty-two students from Hungarian higher educational institutions (mainly in the Northern Great Plain) and five higher education institutions abroad were contacted by the snowball method. In total, 605 individuals completed the questionnaire. Based on the results of the qualitative research, our research team formulated several statements in the questionnaire that could be reasons for dropout, as identified by the students; these are listed in the Appendix. These statements (those listed in the Appendix) had to be evaluated on a 
4-point Likert scale, and the following four clusters were created, based on the statements in the quantitative phase:

1. Students dropping out due to financial reasons and work

2. Students highlighting academic and institutional reasons

3. Students identifying various reasons

4. Students disappointed and losing motivation

We examined the role of civic activity and employment in student dropout, along with the following clusters.

\subsection{The appearance of volunteering in the life of those dropping out}

$28 \%$ of the dropped-out students did volunteering during their academic studies. As could already be noted, in 2013, 26.1\% of students volunteered during their higher education course (Fényes, 2014), while this proportion was 38.8\% in 2015 (Markos, 2018). Thus, dropped-out students seem to do voluntary work to a lesser extent than higher education students in general.

The motivation for volunteering was studied on the basis of the Volunteer Functions Inventory (VFI) (Clun et al.,1998), which includes a 20 item Likert scale (Figure 1). The statistics show that volunteers who had already dropped out of higher education were primarily characterised by altruistic motivation (helping others, feeling better), followed by individualistic elements (work experience, new knowledge, making friends). Previous studies measuring volunteers studying in higher education also show that young people can be characterized by mixed motivations, i.e. by both altruistic and individualistic motivations (Fényes, 2015; Stefanescu \& Osvat, 2011).

Figure 1. The distribution of the types of motivation for volunteering (\%) (N=605). Source: DEPART 2018

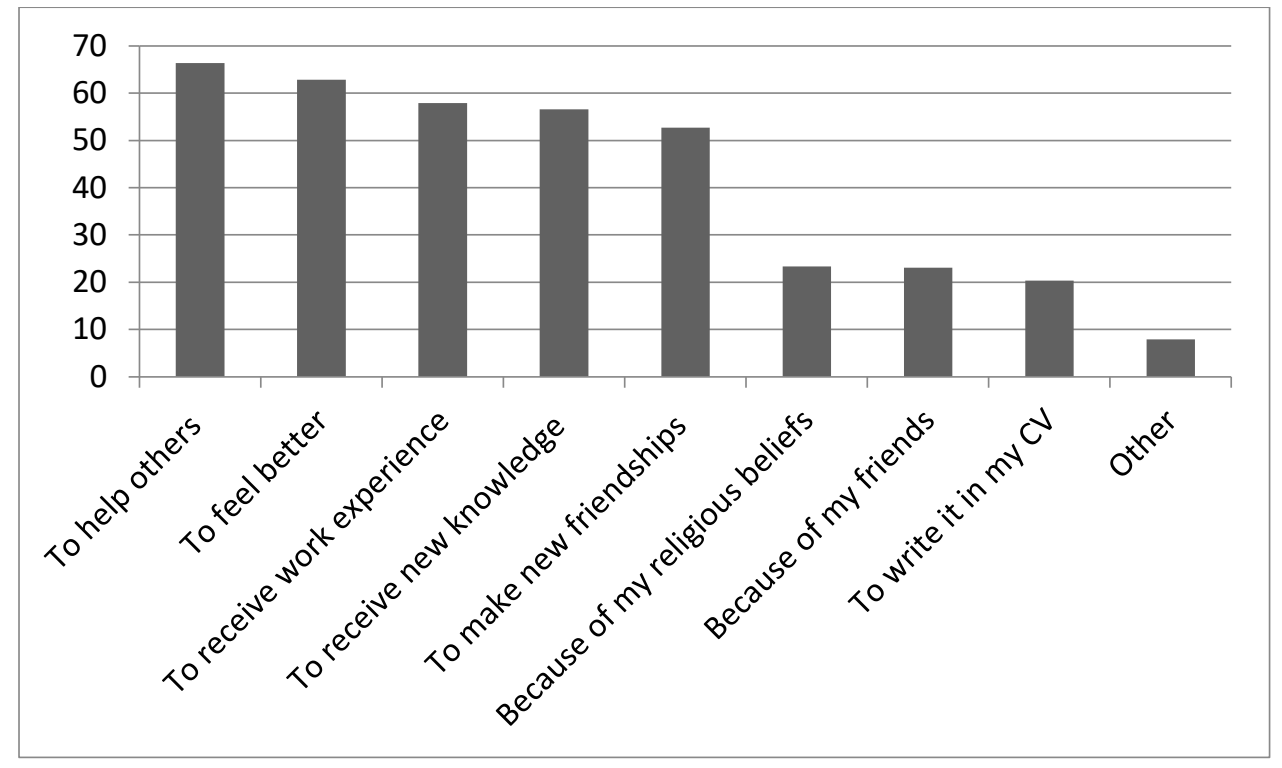

We examined the correlation between students as cluster members and the motivational items. A significant correlation could be found between helping others and the cluster groups. $75.4 \%$ of students who had dropped out due to financial reasons and work reported that helping others was important during their volunteering. This proportion was $67.1 \%$ among students dropping out for academic and institutional reasons, $69.1 \%$ among those identifying various reasons and $46.5 \%$ among those who are disappointed in the course and further education in general. Although previous research has shown that a better financial situation has a positive effect on volunteering (Fényes, 2015), according to our data, helping others was the most important for those coping with financial difficulties. Thus, altruistic motivation, which is supposedly the result of a sense of solidarity, is primarily characteristic of those with financial problems, while it is least likely to be characteristic of those disappointed in the course. 
Also, a significant correlation could be detected between work experience and cluster groups. Gaining work experience was the most important motivation for volunteering for those who identified various causes (64.6\%), followed by those dropping out due to academic and institutional reasons $(60.6 \%)$, those dropping out due to financial reasons and work (59.3\%) and those disappointed in the course and further education in general (38.1\%). Thus, it seems that the individual volunteering motivation is the most characteristic of those mentioning several reasons as being behind their decision to drop out. Gaining work experience during volunteering was the least important for those disappointed in the course and further education, and for those who dropped out due to financial reasons and work. This may be due to the fact that these two groups might have had paid work during their studies, so it was less important for them to gain work experience through voluntary work.

Table 1. The motivations for volunteering and the relationships among the cluster groups (column\%). Source: DEPART 2018

\begin{tabular}{|c|c|c|c|c|c|c|}
\hline & $\begin{array}{l}\text { Students } \\
\text { dropping ov } \\
\text { due } \\
\text { financial } \\
\text { reasons an } \\
\text { work }\end{array}$ & $\begin{array}{l}\text { Students } \\
\text { highlighting } \\
\text { academic } \\
\text { and } \\
\text { institutional } \\
\text { reasons }\end{array}$ & $\begin{array}{l}\text { Students } \\
\text { highlighting } \\
\text { various } \\
\text { reasons }\end{array}$ & $\begin{array}{l}\text { Students } \\
\text { disappointed } \\
\text { and losing } \\
\text { motivation }\end{array}$ & $\mathbf{N}$ & Sig \\
\hline To get new & & & & & & \\
\hline knowledge & & 53.3 & 61.2 & 47.7 & 261 & NS \\
\hline To feel better & 73 & 58.6 & 63.1 & 54.2 & 257 & NS \\
\hline To help others & & & & & & \\
\hline & 75 & 67.1 & 69.1 & 46.5 & 255 & 0,018 \\
\hline To make new & & & & & & \\
\hline friendships & 59 & 49.3 & 53.7 & 45.2 & 257 & NS \\
\hline $\begin{array}{l}\text { To get work } \\
\text { experience }\end{array}$ & 59 & 60.6 & 64.6 & 38.1 & 251 & 0,038 \\
\hline $\begin{array}{l}\text { Because of my } \\
\text { friends }\end{array}$ & 28 & 16.9 & 21.3 & 27.9 & 254 & NS \\
\hline To write it in my & & & & & & \\
\hline $\mathrm{CV}$ & & 21.7 & 23.8 & 11.6 & 250 & NS \\
\hline $\begin{array}{l}\text { Because of my } \\
\text { beliefs }\end{array}$ & & 21.7 & 23.5 & 23.8 & 252 & NS \\
\hline Other & 7 & 6.5 & 11.1 & 5.3 & 114 & NS \\
\hline
\end{tabular}

In addition to volunteering, we examined the civic activity of the students, which was done by mapping their membership of organisations. Students are primarily members of cultural $(16.1 \%)$, church $(15.1 \%)$, sports $(13.1 \%)$ and civic $(10.2 \%)$ organisations. A smaller proportion of students are members of charity organisations (8\%), research groups (6.5\%), Students' Unions (HÖK) $(5.9 \%)$, political (4.1\%) and other organisations (3\%). The data from the Hungarian Youth Survey 2016 show a similar tendency: according to the research, young people primarily join sports organisations, student organisations and leisure (e.g. cultural) organisations, while participation in denominational organisations is very low ( $2 \%)$.

We have examined whether a correlation exists between the clusters and different organisational memberships.

Those belonging to cultural and traditional groups are overrepresented among those who dropped out due to financial reasons or because of their multiple obligations, while the members of denominational organisations are slightly more likely to be found among those dropping out for various reasons and those disappointed in the course. These voluntary activities are generally 
appropriate for supporting the commitment, embeddedness and persistence of students in their studies. However, if higher education institutions do not consider cultural programs and organisations to be culturally worthwhile, and do not support them, then students will participate in these activities outside the institution, which will obviously link them to external networks. Weak attachment to the internal communication network is identified by the literature as a factor contributing to inefficiency and dropout (Pusztai, 2011).

Concerning civic organisations, the largest proportion of students were those who had dropped out for academic and institutional reasons, followed by those who dropped out due to financial reasons and work. Students highlighting various reasons and those disappointed in the course were the least frequently represented among members of non-governmental organisations. The critical thinking of members of civil society organisations may become stronger, leading to the development of self-criticism and the ability to critically evaluate the environment, perhaps also helping to explain dropout for educational and institutional reasons.

Despite the fact that membership of political organisations is rare, there is a significant correlation with the clusters. It can be seen that the membership of political organisations was highest among students dropping out for financial reasons and work, followed by those disappointed in the faculty and further education, those dropping out for academic and institutional reasons and those reporting various reasons. The probable reason for this is that students in a worse financial situation are more likely to join political organisations with the hope of improving their economic situation.

Table 2. The connection between organisational membership and cluster groups (column $\%)(p \leq 0,05)$. Source: DEPART 2018

\begin{tabular}{|c|c|c|c|c|c|c|}
\hline & $\begin{array}{c}\text { Students } \\
\text { dropping } \\
\text { out due to } \\
\text { financial } \\
\text { reasons and } \\
\text { work }\end{array}$ & $\begin{array}{c}\text { Students } \\
\text { highlighting } \\
\text { academic and } \\
\text { institutional } \\
\text { reasons }\end{array}$ & $\begin{array}{c}\text { Students } \\
\text { highlighting } \\
\text { various } \\
\text { reasons }\end{array}$ & $\begin{array}{c}\text { Students } \\
\text { disappointed } \\
\text { and losing } \\
\text { motivation }\end{array}$ & $\mathbf{N}$ & Sig \\
\hline $\begin{array}{l}\text { Civic } \\
\text { organisation }\end{array}$ & 11.9 & 15.2 & 6.5 & 6.5 & 539 & 0,037 \\
\hline Sports club & 13.3 & 14.7 & 10.5 & 14.5 & 540 & NS \\
\hline $\begin{array}{l}\text { Denominatio } \\
\text { nal } \\
\text { organisation }\end{array}$ & 13.6 & 13.3 & 16.6 & 16.3 & 535 & NS \\
\hline $\begin{array}{l}\text { Political } \\
\text { organisation } \\
\text { Students' }\end{array}$ & 8.5 & 3.5 & 1.3 & 4 & 535 & 0,030 \\
\hline Union & 7.6 & 5.6 & 6.6 & 4 & 537 & NS \\
\hline $\begin{array}{l}\text { Research } \\
\text { group }\end{array}$ & 6.8 & 6.8 & 7.3 & 4.9 & 535 & NS \\
\hline $\begin{array}{l}\text { Cultural } \\
\text { group }\end{array}$ & 18.6 & 13.4 & 17.3 & 15 & 530 & NS \\
\hline $\begin{array}{l}\text { Charity } \\
\text { group }\end{array}$ & 9.2 & 9.8 & 9 & 3.3 & 539 & NS \\
\hline Other & 6.9 & 0.8 & 2.4 & 2.7 & 465 & NS \\
\hline
\end{tabular}

As regards volunteering, it can be seen that the proportion of volunteers was lower among dropped-out students compared to their peers who are studying. Regarding their motivation, it can be observed that the most important thing among students who dropped out due to financial reasons and work was to help others, while getting work experience was the most important for those who identified various reasons. Gaining work experience was least important for those who were disappointed with the course and further education, and for those who dropped out due to financial 
reasons and work, as they already had paid work during their studies and so it was less important for them to gain work experience during voluntary work. Students are primarily members of cultural, denominational, sports and civic organizations. The largest proportion of the members of civil society organisations were students who dropped out for academic and institutional reasons. Civil organisation membership can increase critical thinking, which contributed to the explanation of the reasons for students dropping out for academic and institutional reasons. Among the members of political organisations, most were students who had dropped out for financial reasons and work, which is probably due to the fact that students in a worse financial situation are more likely to join political organisations with the hope of improving their financial situation.

\subsection{Students faced with the dual attraction of work and study}

During our research, we examined the frequency of work, the reasons for work, and the relationship between work and studies. Similarly to previous studies (Kocsis, 2017; Masevičiūtè et al., 2018) we also reported low numbers of students whose work was related to their studies, with $23 \%$ of students reporting doing this kind of work. Consequently, in what follows, we focus on the frequency of work and what motivated the decision to work. The values of the frequency of work are defined as never, yearly, monthly and weekly.

In the first part of the analysis, we examined the relationships between the variables mentioned above and the dropout clusters. Firstly, we analysed whether there was a significant correlation between the frequency of employment and the clusters created on the basis of reasons for dropout. $39 \%$ of students who dropped out due to financial reasons and work were involved in regular employment on a weekly basis, and a fifth on a monthly basis. The negative effects of employment have also been proved by previous research, according to which a higher dropout ratio can be detected among students who are in permanent employment, as they are severely hindered in participating in their courses (Curtis \& Shani, 2002; Darmody \& Smyth, 2008). A similar employment ratio characterised respondents who dropped out for academic reasons, as $27.5 \%$ worked weekly during their university studies. Furthermore, $28.3 \%$ of those disappointed with further education were employed during their course. If students evaluate the marketability of the degree they are studying negatively, the impact of the labour market will be even greater, and the presence of these two factors may lead to dropout. $26.3 \%$ of the respondents who were unsure regarding the reasons for dropout also had paid weekly work.

Table3. The frequency of employment in the clusters created on the basis of the reasons for dropout $(p=0.000)$ (N=541). Source: DEPART 2018

\begin{tabular}{l|c|c|c|c}
\hline & $\begin{array}{c}\text { Students dropping } \\
\text { out due to } \\
\text { financial reasons } \\
\text { and work }\end{array}$ & $\begin{array}{c}\text { Students } \\
\text { highlighting } \\
\text { academic and } \\
\text { institutional } \\
\text { reasons }\end{array}$ & $\begin{array}{c}\text { Students } \\
\text { highlighting various } \\
\text { reasons }\end{array}$ & $\begin{array}{c}\text { Students } \\
\text { disappointed and } \\
\text { losing motivation }\end{array}$ \\
\hline weekly & $39.0 \%$ & $27.5 \%$ & $26.3 \%$ & $28.3 \%$ \\
monthly & $21.2 \%$ & $10.1 \%$ & $8.6 \%$ & $11.5 \%$ \\
yearly & $6.8 \%$ & $13.4 \%$ & $17.1 \%$ & $12.4 \%$ \\
never & $33.1 \%$ & $49.0 \%$ & $48.0 \%$ & $47.9 \%$ \\
\hline
\end{tabular}

As the next step in our research, we examined whether there is a difference between the clusters and the motives for employment. The motivation for work is usually related to the familial and financial background of student and the relationship between the student's job and their studies. Previous research shows that most students work to finance their living costs and to gain work experience, while the motivation of financing their entertainment appears to a lesser degree (Bocsi et al., 2017; Kocsis, 2017; Kóródi, 2007). In the Balkan countries, the main motivation for students to work is to pay tuition fees and to cover their daily expenses. In addition, students work to gain work 
experience and to support someone else financially (their families, children) (Masevičiūtè et al., 2018). The ratio of those quitting their studies before the first degree is one and a half times higher in correspondence courses, and three times higher in fee-paying courses compared to their full time or state-funded equivalents (Fónai, 2018, p. 247). Tuition fees, financial burdens, and the constraints of employment can all trigger dropout. In our current sample, $33 \%$ of the respondents continued their last course in a cost reimbursement form, but the tuition fee as a motivational factor affected $24 \%$ of the respondents and the need to pay their fees was their entire motivation for working.

The clusters of the respondents who dropped out for financial reasons and those disappointed with their course show a correlation with work motivation, although it should be noted that we did not find any significant correlation between clusters and work motivations (Figure 3). Students who drop out due to financial reasons and work are most likely to work because of their financial burdens. $41 \%$ of them undertook paid work to cover their living expenses, while $32 \%$ did so to cover their tuition fees. Due to employment and material burdens, these students are likely to have found themselves in a sort of vicious circle, as their work has had a negative impact on their academic success, and so they have dropped out, although they may have been in a financially more favourable position.

Figure 3. The connection between the reasons for employment and the reasons for dropout ( $>0.05)(\mathrm{N}=605)$. Source: DEPART 2018

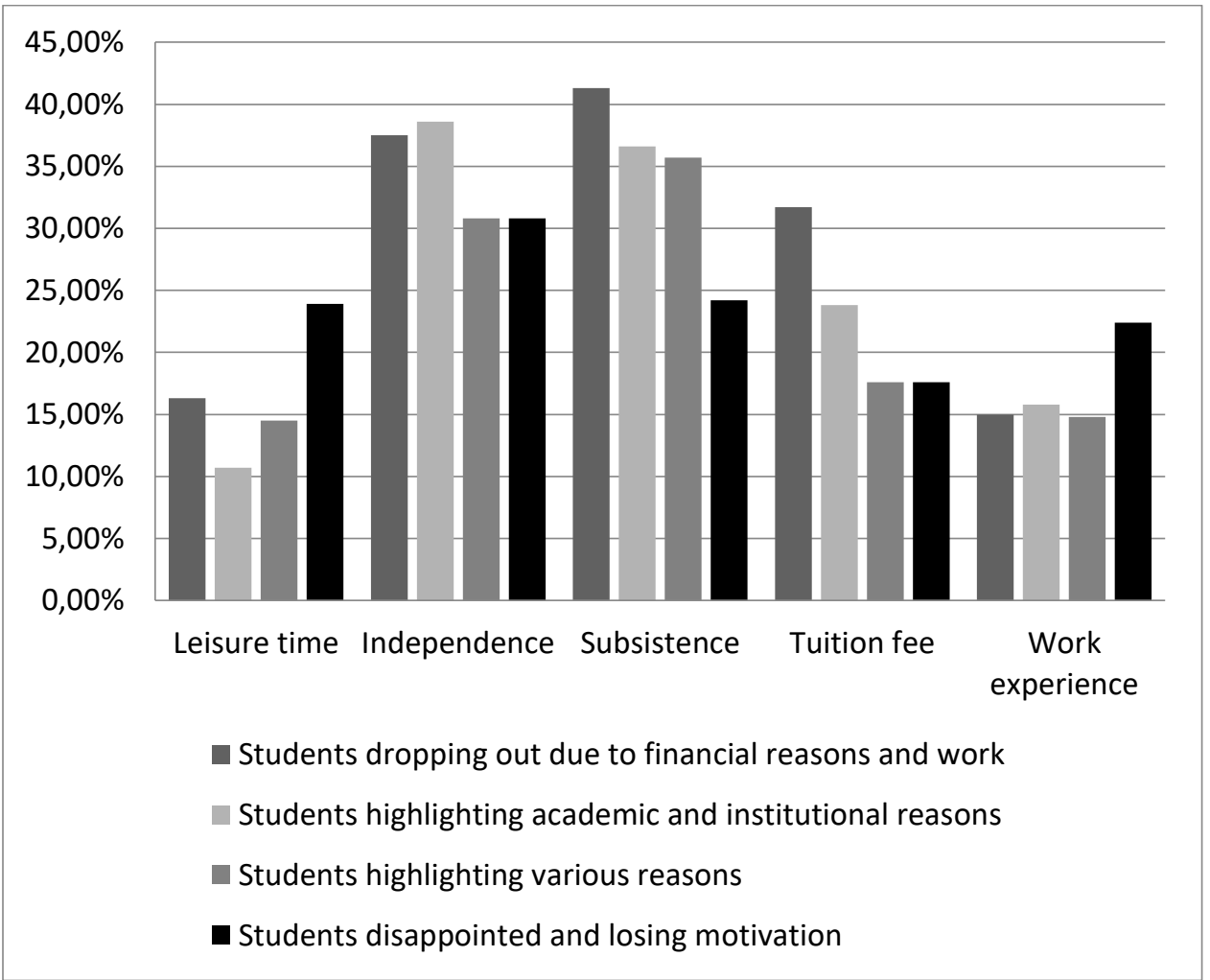

However, respondents disappointed with the course and in further education were motivated by the chance to gain work experience and new acquaintances. $22 \%$ of those who were disappointed with their further educational studies were working specifically to gain work experience, while $19 \%$ were working to get new acquaintances at work. Based on the results, it can be assumed that the negative assessment of the studies or the disappointment with the course will increase the attractiveness of the labour market, so these young people preferred to find themselves in the labour market instead of completing their university studies. The subtractive effect of the labour market was not only significant during the university years, but also after the interruption of studies. $52 \%$ of the dropped-out students, after quitting their studies, were employed in Hungary, and the proportion of those who applied for another course or who started to work abroad was very low. Work abroad is 
a special type of employment, which can have positive effects on higher education studies, such as learning a language, increased engagement, and gaining professional experience. However, it can also have negative effects, such as the general contraction of the labour market and the strengthening of migration. 46 respondents $(8.6 \%)$ worked abroad during their higher educational years, but there was no significant correlation with the dropout clusters. It can be assumed that identifying the potential positive or negative effects and relationships of foreign employment would require a larger sample.

\section{Results}

In our current research, the role of civic activity and student work was examined in the development of dropout. For this reason, we examined how often and for what reasons the students performed the following activities. According to our results, $28 \%$ of the dropped-out students did volunteering during their university studies. Concerning volunteering, it could be seen that the proportion of volunteering is lower among the dropped-out students compared to those studying. As the literature suggests that volunteering contributes to deeper engagement in studies, it would be important in the future to promote the possibility of volunteering, or to incorporate it into the course as a service-learning program. Similar results were obtained in the examination of employment, with the finding that $28 \%$ of the respondents have regular work on a weekly basis and $11 \%$ on a monthly basis. On average a quarter of respondents have undertaken regular employment, with the highest rate of students dropping out doing so for financial and work reasons, followed by those disappointed in their field of studies and further education.

In both cases, we analysed what motivated the dropped-out students to volunteer and to do paid work. In terms of volunteering, we found a significant correlation between gaining work experience and the clusters. Gaining work experience was the most important volunteering motivation for students identifying various reasons $(64.6 \%)$, followed by those dropping out for academic reasons $(60.6 \%)$, those dropping out for material reasons and work $(59.3 \%)$ and those disappointed with the course and further education (38.1\%). Gaining work experience was the least important for those disappointed with the course and further education, and for those who dropped out due to financial reasons and work. This may be due to the fact that, regarding the motivation of paid work, the cluster of students disappointed with the course and with further education was the most important because they were motivated mostly by working experience and getting new acquaintances during employment. For the majority of the respondents, motivation for work was determined by material reasons, and they mentioned the need for independence from their parents, the financing of everyday expenses and tuition fees. Motivational factors such as work experience and getting new acquaintances motivated students to work to a lesser degree, but these factors are the most important for acquiring future benefits.

Our results suggest that it would be worthwhile to place more emphasis on career guidance programs, so that applicants can get a more accurate image of what they have chosen, thereby reducing their chances of becoming disappointed with university education and giving them more access to the labour market. We assume that employment during higher education will be an issue that students will face in their studies, and so it would be beneficial if the higher educational institution puts more emphasis on practical training, cooperation with practical placements, and dual training. In this way, students would have the opportunity to be employed in a job related to their profession, thereby gaining not only professional experience but also financial security, thus reducing the risk of dropping out of work. Thus, working while at university would not be a risk factor, but a supportive factor that would be one of the drivers for future success and employment.

Funding: Project no. 123847 has been implemented with the support provided by the National Research, Development and Innovation Fund of Hungary, financed under the K-17 funding scheme.

Conflicts of Interest: The authors declare no conflict of interest.

\section{References}


1. Astin, A. W. (1993). What Matters in College: Four Critical Years Revisited. San Francisco: Jossey-Bass.

2. Baert, S. \& Vujić, S. (2018). Does it pay to care? Volunteering and employment opportunities. J Popul Econ, 31, 819-836

3. Beerkens, M., Mägi E., Lill, L. (2011). University studies as a side job. Causes and consequences of massive student employment in Estonia. Higher Education, 61(6), 679-692.

4. Berei, E. B. (2018). Chronic illness in higher education? The risk of dropout among disadvantaged students [Krónikus betegség a felsőoktatásban? Lemorzsolódás kockázat hátrányos helyzetü hallgatók körében.] In: Pusztai G. \& Szigeti F. (szerk.). Dropout and persistence in higher education. [Lemorzsolódás és perzisztencia a felsőoktatásban] (pp. 284-299). Debrecen: Debreceni Egyetemi Kiadó.

5. Bocsi, V., Fényes, H. \& Markos, V. (2017). Motives of volunteering and values of work among higher education students. Citizenship Social and Economics Education, 16(2), 117-131.

6. Bocsi, V., Ceglédi, T., Kocsis, Zs., Kovács, K. E., Kovács, K., Müller A., Pallay, K., Szabó, B. É., Szigeti, F. \& Tóth, D. A (2018). Dropout and persistence in higher education. [A pedagógushallgatók késleltetett diplomaszerzése interjúk alapján.] In: Pusztai G. \& Szigeti F. (szerk.), Dropout and persistence in higher education. [Lemorzsolódás és perzisztencia a felsőoktatásban] (pp. 63-61). Debrecen: Debreceni Egyetemi Kiadó.

7. Clary, Gil.E., Snyder, M., Ridge, R., Stukas, A., Copeland, J., Haugen, J. \& Miene, P. (1998). Understanding and Assessing the Motivations of Volunteers: A Functional Approach. Journal of Personality and Social Psychology, 74(6), 1516-1530.

8. Curtis, S. \& Shani, N. (2002). The effect of taking paid employment during term-time on students' academic studies. Journal of Further and Higher Education, 26(2), 129-138.

9. Darmody, M. \& Smyth, E. (2008). Full-time students? Term-time employment among higher education students in Ireland. Journal of Education and Work, 21(4), 349-362.

10. Derényi, A. (2015). Evidence-based governance and communication training [Bizonyítékokra alapozott kormányzás és a kommunikáció képzés.] Jelkép, 1-21.

11. Dusa, Á. R., Csók C., Hrabéczy A., Ilyésné Novák I., Karászi Zs., Ludescher G., Markos V. \& Németh D. (2018). Exploring background factors affecting student dropouts in the light of qualitative research. [A hallgatói lemorzsolódást befolyásoló háttértényezők feltárása egy kvalitatív kutatás tükrében.] In: Pusztai G. \& Szigeti F. (szerk.). Dropout and persistence in higher education. [Lemorzsolódás és perzisztencia a felsőoktatásban] (pp. 38-63). Debrecen: Debreceni Egyetemi Kiadó.

12. Fényes, H. (2014). Volunteering and a new type of volunteering among students in Debrecen [Önkéntesség és új típusú önkéntesség a debreceni egyetemisták körében.] In: Fényes H. \& Szabó I. (szerk.) Campus-being at the University of Debrecen. Youth Sociology Studies [Campus-lét a Debreceni Egyetemen. Ifjúságszociológiai tanulmányok.] Debrecen: Debreceni Egyetemi Kiadó

13. Fényes, H. (2015). Volunteering and a new type of volunteering among higher educational students. [Önkéntesség és új típusú önkéntesség a felsőoktatási hallgatók körében.] Debrecen: Debreceni Egyetemi Kiadó. 9-46.

14. Fényes, H., Markos, V. \& Pusztai, G. (2017). Civic activity of higher educational students and the correlation between their dropout rates. [A felsőoktatási hallgatók civil aktivitása és a lemorzsolódási esélyük összefüggései.] Metszetek, 7 (3) 141-156.

15. Fónai, M. (2018). Student dropout at the University of Debrecen. [Hallgatói lemorzsolódás a Debreceni Egyetemen.] In: Pusztai G. \& Szigeti F. (szerk.). Dropout and persistence in higher education. [Lemorzsolódás és perzisztencia a felsőoktatásban] Debrecen: Debreceni Egyetemi Kiadó. 239-250.

16. Hustinx, L. (2001). Individualisation and new styles of youth volunteering: An empirical exploration. Volunt. Action, 3, 57-76.

17. Hunstinx, L., Vanhove, T., Declercq, K. \& Lammerty, F. (2005). Bifurcated commitment, priorities, and social contagion: The dynamics and correlates of volunteering within a university student population. British Journal of Sociology of Education, 26(4) 524-538.

18. Juknevicius, S. \& Savicka, A. (2003). From Restitution to Innovation: Volunteering in Postcommunist Countries. In Dekker, P. \& Halman, L. (eds.): The Values of Volunteering. Cross-Cultural Perspectives. Kluver Academic/Plenum Publishers. New York, Boston, Dordrecht, London, Moscow, 127-141.

19. Kocsis, Zs. (2017). The characteristics of student employment among university students in Debrecen and Nyíregyháza. [A hallgatói munkavállalás jellemzői a debreceni és a nyíregyházi egyetemisták körében.] PedActa, 7(1), 81-89.

20. Kóródi, M. (2007). Examining work values in two higher education institutions. [Munkaértékek vizsgálata két felsőoktatási intézményben.] Educatio, 16(2), 311-322. 
21. Kozma, T. (2006). The bases of the comparative educational science. [Az összehasonlító neveléstudomány alapjai.] Budapest: Új Mandátum.

22. Markos, V. (2014). University students int he world of work. [Egyetemisták a munka világában.] In: Fényes H. \& Szabó I. (szerk.). Campus-being at the University of Debrecen. Youth Sociology Studies [Campus-lét a Debreceni Egyetemen. Ifjúságszociológiai tanulmányok.] (pp. 109-132.). Debrecen: Debreceni Egyetemi Kiadó.

23. Markos, V. (2018). Examining the family background and work value preferences of volunteer and paid students. [Az önkéntes és fizetett munkát végző hallgatók családi hátterének és munkaérték preferenciáinak vizsgálata.] PedActa, 8(2) 1-16.

24. Masevičiūtè, K., Šaukeckienè, V. \& Ozolinčiūtè, E. (2018). EUROSTUDENT VI. Combining Studies and Paid Jobs.

25. McCoy, S., \& Smyth, E. (2004). At work in school. Dublin: ESRI/Liffey Press

26. Pascarella, E.T., Edison, M.I., Nora, A., Hagedorn, L.S. \& Terenzini, P.T. (1998). Does Work Inhibit Cognitive Development during College? Educational Evaluation and Policy Analysis, 20(2), 75-93.

27. Perna, L. (2012). Understanding the Working College Student New Research and Its Implications for Policy and Practice. Sterling: Stylus Publishers.

28. Pusser, B. (2010). Of a mind to labor: Reconceptualizing student work and higher education. In: L.W. Perna (eds.). Understanding the working college student: New research and its implications for policy and practice. (pp. 134-155). Sterling: Stylus Publishers

29. Pusztai, G. (2011). The invisible hand to the hands of friends. Student Interpreting Communities in Higher Education. [A láthatatlan kéztôl a baráti kezekig. A hallgatói értelmező közösségek a felsőoktatásban.] Budapest: Új Mandátum.

30. Riggert, S.C., Boyle, M., Petrosko, M.J., Ash, D. \& Rude-Parkins, C. (2006). Student Employment and Higher Education: Empiricism and Contradiction. Review of Educational Research, 76(1), 63-92.

31. Roshchin, S. \& Rudakov, V. (2015). Russian University student and the combination of study and work: is it all about earning, learning or job market signaling?

https://memo.hse.ru/data/2015/03/18/1092801357/Roshchin,\%20Rudakov_Russian\%20university\%20stude nts.pdf.

32. Sanchez-Gelabert, A., Figueroa, M. \& Elias, M. (2017). Working whilst studying in higher education. The impact of the economic crisis on academic and labour market success. European Journal of Education, 52 (2), 232-245.

33. Szabó I. (2009). Nation and socialisation. [Nemzet és szocializáció.] Budapest: L'Harmattan Kiadó.

34. Szőcs A. (2013). Working relationship and relationship to work - students at the University of Debrecen. [Munkaviszony és viszony a munkához - hallgatók a Debreceni Egyetemen.] In: Darvai T. (ed.). Higher education and the labour market - from ideal to competence. [Felsőoktatás és munkaerópiac - eszményektól a kompetenciák felé] (pp. 87-124.). Szeged: SETUP-Belvedere Kiadó.

35. Szőcs A. (2014). A smooth sea does not make a skilled sailor: students' relationship to work at the University of Debrecen. [Teher alatt nő a pálma: hallgatók munkához való viszonya a Debreceni Egyetemen.] In: Fényes H. \& Szabó I. (szerk.). Campus-being at the University of Debrecen. Youth Sociology Studies [Campus-lét a Debreceni Egyetemen. Ifjúságszociológiai tanulmányok.] (pp. 159-182.). Debrecen: Debreceni Egyetemi Kiadó.

36. Stefanescu, F. \& Osvat, C. (2011). Volunteer Landmarks among College Students. The Yearbook of the "Gh. Zane" Institute of Economic Researches, 20(2), 139-149.

37. Stiburek, Š., Vlk, A. \& Švec, V. (2017). Study of the success and dropout in the higher education policy in Europe and V4 countries. Hungarian Educational Research Journal, 7(1), 43-56.

38. Volunteurope (2018). Measuring the impact of volunteering. Position Paper. https://volonteurope.eu/wpcontent/uploads/2018/03/Measuring-impact-_Paper_Final.pdf.

\section{Documents}

39. Központi Statisztikai Hivatal (2011): Önkéntes munka Magyarországon [Volunteering in Hungary] www.ksh.hu/docs/hun/xftp/idoszaki/pdf/onkentesmunka.pdf.

40. Központi Statisztikai Hivatal (2016) Az önkéntes munka jellemzöi. [Characteristics of volunteering.] https://www.ksh.hu/docs/hun/xftp/idoszaki/pdf/onkentes.pdf.

41. Hungarian Youth $2016 \quad$ [Magyar Ifjúság

http://www.ujnemzedek.hu/sites/default/files/magyar_ifjusag_2016_a4_web.pdf. 